\title{
Composition of bacterial community and isolation of bacteria responsible for diuron degradation in sediment and soil under anaerobic condition
}

Ha Danh Duc ( $\square$ hadanhduc@gmail.com )

Dong Thap University https://orcid.org/0000-0002-4862-2082

Oanh Thi Nguyen

Dong Thap University

\section{Research Article}

Keywords: diuron, degradation, anaerobic conditions, microbial community, metabolites

Posted Date: September 28th, 2021

DOI: https://doi.org/10.21203/rs.3.rs-812618/v1

License: (c) (i) This work is licensed under a Creative Commons Attribution 4.0 International License.

Read Full License 


\section{Abstract}

The herbicide diuron is extensively used in the agriculture sector and is detected widely in the environment. Although several studies on the degradation of diuron by aerobic micro-organisms have been reported, the degradation of diuron by anaerobic micro-organisms has not been received much attention. Also, no pure culture that can degrade diuron under anaerobic conditions has yet been reported. The evaluation of diuron degradation in the soil and sediment slurries showed that diuron led to a decrease in the biodiversity of the bacterial communities. Two mixed bacterial cultures, one from the soil and the other from sediment slurries, were isolated from the enrichment media under anaerobic conditions. After 30 days of incubation at $30^{\circ} \mathrm{C}$, the mixed bacterial culture from the soil degraded $84.5 \pm$ $5.5 \%$, and that from the sediment slurry degraded $94.5 \pm 3.0 \%$ of diuron in liquid mineral medium at an initial concentration of $20 \mathrm{mg} / \mathrm{L}$. 1-(3,4-dichlorophenylurea (DCPU), 3-(3-chlorophenyl)-1,1-dimethylurea (CPDMU), and 3,4-dichloroaniline (3,4-DCA) were the major diuron metabolites produced by both the indigenous micro-organisms and the isolated bacteria.

\section{Introduction}

Diuron [3-(3,4-dichlorophenyl)-1,1-dimethylurea], a selective herbicide, is extensively used for controlling a wide range of weeds and grasses in agricultural crop and non-crop areas worldwide. It inhibits photosynthesis by preventing oxygen production and blocks electron transfer in photosystem II by binding to plastoquinone binding site (Giacomazzi and Cochet 2004). Diuron is slightly toxic to mammals and birds and moderately toxic to aquatic invertebrates (Giacomazzi and Cochet 2004). Diuron has been widely detected in surface water and groundwater at concentrations above the European Union threshold limit (Field et al. 2003; Landry et al. 2006; Dores et al. 2009) and has also been detected in seawater and marine sediment samples (Thomas et al. 2001), river sediments (Matthai et al. 2009) and soil (Field et al. 2003). The herbicide is persistent in soil, water, and groundwater (Giacomazzi and Cochet 2004), with a half-life in soil ranging from one month to one year (Wauchope et al. 1992). Diuron is identified as a priority hazardous substance by the European Commission and is banned in Europe (Malato et al. 2002).

Diuron undergoes hydrolysis and photolysis at very low rates under natural conditions (Giacomazzi and Cochet 2004). However, dissipation of diuron from the environment occurs mainly by microbial transformation (Sørensen et al. 2003). Under aerobic conditions, N-dimethylation is the major metabolic transformation leading to the formation of metabolites such as DCPMU, DCPU, and 3,4-DCA, which are detected in the soil and the groundwater along with the parent compound. (Thomas et al. 2001; Gooddy et al. 2002; Coelho-Moreira et al. 2013; Coelho-Moreira et al. 2018).

Aerobic biodegradation of diuron is well-studied (Coelho-Moreira et al. 2018; Felício et al. 2018; Hanapiah et al. 2018), but the research on the anaerobic degradation is lacking (Attaway et al. 1982a; Attaway et al. 1982b). Several aerobic diuron-degrading bacteria and fungi have been isolated, e.g., Arthrobactersp. BS2 and Achromobactersp. SP1 (Devers-Lamrani et al. 2014), Stenotrophomonas acidophila TD4.7 and 
Bacillus cereus TD4.31 (Egea et al. 2017), Mortierella (Ellegaard-Jensen et al. 2013), Arthrobacter sulfonivorans, Variovorax soli, and Advenella sp. JRO (Villaverde et al. 2017), Ganoderma lucidum (Coelho-Moreira et al. 2018), Comamonas jiangduensis SZZ 10 and Bacillus aerius SZZ 19 (Hanapiah et al. 2018), and Bacillus spp. (Muendo et al. 2021). However, to the best of our knowledge, isolation of a diuron-degrading bacterial strain in pure cultures has not been reported. Moreover, the effect of diuron on the indigenous microbial population has been studied under aerobic conditions (Prado and Airoldi 2001; Moretto et al. 2017), and the corresponding studies under anaerobic conditions are lacking, and the degradation pathway of diuron under anaerobic conditions is still unclear.

In this study, we have investigated the effect of diuron on the composition of the bacterial communities in the soil and the sediment slurries under anaerobic conditions and tried to fill the existing knowledge gap. We describe the anaerobic pathways for degradation of diuron by the indigenous microbial community and the isolated bacterial cultures.

\section{Materials And Methods}

\section{Anaerobic degradation of diuron in soil and sediment slurries}

Soil samples were collected from a cornfield (Tra Vinh Province, Vietnam) and the sediment slurries from Hau River (one of the two main sections of Mekong River) in an area near the field, where water was discharged from the fields. The samples were collected at a depth of $20-25 \mathrm{~cm}$ from an area of approximately $10 \mathrm{~m}^{2}$ for the soil and $5 \mathrm{~m}^{2}$ for the sediments. The soil samples were mixed and passed through a sieve with an aperture of $2.0 \mathrm{~mm}$ diameter to remove large debris. The sediments were also mixed and sieved. The samples were kept in plastic bags in iceboxes containing frozen ice packs and transported to the laboratory within a day. The physicochemical properties of the soil and the sediment slurry were analyzed using the American Public Health Association method (APHA) (APHA 2005), and the results are presented in Table 1. 
Table 1

Physicochemical properties of dry sediment

\begin{tabular}{|llll|}
\hline Composition & Units & \multicolumn{2}{l|}{ Statistics } \\
\cline { 2 - 4 } & & Sediment & Soil \\
\hline Clay & $\%$ & 22.5 & 20.9 \\
\hline Silt & $\%$ & 38.3 & 22.7 \\
\hline Sand & $\%$ & 39.2 & 56.4 \\
\hline $\mathrm{pH}$ & & 6.2 & 6.5 \\
\hline Total organic carbon & $\mathrm{g} / \mathrm{kg}$ & 6.8 & 5.4 \\
\hline Total nitrogen & $\mathrm{g} / \mathrm{kg}$ & 0.71 & 0.58 \\
\hline Si & $\mathrm{g} / \mathrm{kg}$ & 324.4 & 566.4 \\
\hline Al & $\mathrm{g} / \mathrm{kg}$ & 37.6 & 58.8 \\
\hline Ca & $\mathrm{g} / \mathrm{kg}$ & 12.5 & 15.7 \\
\hline Fe & $\mathrm{g} / \mathrm{kg}$ & 14.4 & 21.6 \\
\hline $\mathrm{Mg}$ & $\mathrm{g} / \mathrm{kg}$ & 10.4 & 8.3 \\
\hline $\mathrm{K}$ & $\mathrm{g} / \mathrm{kg}$ & 7.4 & 8.5 \\
\hline $\mathrm{S}$ & $\mathrm{g} / \mathrm{kg}$ & 0.8 & 2.2 \\
\hline $\mathrm{P}$ & $\mathrm{g} / \mathrm{kg}$ & 0.7 & 1.11 \\
\hline $\mathrm{Mn}$ & $\mathrm{g} / \mathrm{kg}$ & 0.3 & 0.5 \\
\hline
\end{tabular}

The soil and sediments were mixed with pure, sterile water in a 1:10 ratio w/w. Slurries $(30 \mathrm{~mL})$ were transferred into $75 \mathrm{~mL}$ glass vials, and $\mathrm{NaNO}_{3}$ and glucose were added to a final concentration of 1.0 $\mathrm{g} / \mathrm{L}$. Diuron $(20 \mathrm{mg} / \mathrm{L})$ and redox dye Resazurin $(0.5 \mathrm{mg} / \mathrm{L})$ were also added, and the vials were flushed with Helium gas to exclude oxygen before sealing. Sterile controls were generated by autoclaving the vials at $121^{\circ} \mathrm{C}$ for $15 \mathrm{~min}$ and vials were incubated in the dark at $150 \mathrm{rpm}$ and $30^{\circ} \mathrm{C}$. Samples that did not contain nitrate and glucose were incubated in parallel.

\section{Bacterial diversity and relative abundance in sediments and soil slurries}

Soil and sediment samples were kept at $-80^{\circ} \mathrm{C}$ prior to DNA extraction. The relative abundance of the bacterial species in the sediments and the soil slurries without any additive carbon source were determined by sequencing $16 \mathrm{~S}$ rRNA genes using an Illumina MiSeq bench-top sequencer. Total DNA was directly extracted from $1.0 \mathrm{~g}$ soil using the UltraClean ${ }^{\text {TM }}$ Soil DNA Isolation Kit (Mo Bio Laboratories, 
Inc., Solana Beach, CA, USA). The universal primers 338F (5'-ACTCCTACGGGAGGCAGCAG-3') and 806R (5'-GGACTACHVGGGTWTCTAAT-3') were used to amplify the 16S rRNA genes at the V3-V4 region. The PCR amplifications were performed in $20 \mu \mathrm{l}$ reaction volume using TransGen AP221-02: TransStart Fastpfu DNA polymerase. All amplifications were performed in quadruplicate. Each reaction contained $5 \mathrm{X}$ FastPfu Buffer $(4 \mu \mathrm{L}), 2.5 \mathrm{mM}$ dNTPs $(2 \mu \mathrm{L}), 5 \mathrm{mM}$ Forward Primer $(0.8 \mu \mathrm{L}), 5 \mathrm{mM}$ Reverse Primer $(0.8$ $\mu \mathrm{L})$, FastPfu Polymerase $(4 \mu \mathrm{L}), \mathrm{BSA}(0.2 \mu \mathrm{L})$ and template DNA (10 $\mathrm{ng})$. Initial denaturation step of $3 \mathrm{~min}$ duration at $95^{\circ} \mathrm{C}$ was followed by 27 cycles of $30 \mathrm{~s}$ at $95^{\circ} \mathrm{C}, 30 \mathrm{~s}$ at $55^{\circ} \mathrm{C}$, and $45 \mathrm{~s}$ at $72{ }^{\circ} \mathrm{C}$. The final extension was performed for $10 \mathrm{~min}$ at $72{ }^{\circ} \mathrm{C}$. All PCR products were purified by AxyPrep DNA Gel Extraction Kit (AXYGEN, USA). TruSeq ${ }^{\text {TM }}$ DNA Sample Prep Kit (Illumina, USA) was used to generate the sequencing libraries. The raw sequencing reads were quality controlled using the Trimmomatic (version 0.39) (Bolger et al. 2014). Paired-end reads were merged using FLASH (Magoč and Salzberg 2011). Sequences were grouped into operational taxonomic units (OTUs) based on $97 \%$ identity assigned using the Ribosomal Database Project (RDP) classifier (Wang et al. 2007). Rarefaction and a-diversity indices, i.e., abundance-based coverage estimators (ACE), Chao1, Simpson, Shannon, were analyzed using Mothur software.

\section{Isolation and identification of diuron degrading bacteria from sediment and soil slurries}

The isolation of diuron-degrading bacteria was performed according to the method used in a previous study (Ha 2018). After one month of enrichment, the diluted slurries of the sediment and the soil described above were used to isolate the bacteria. The liquid portion of the enrichment culture was diluted and spread on a solid mineral medium (MM) supplemented with $0.1 \mathrm{mM}$ diuron. The plates were incubated at $30^{\circ} \mathrm{C}$ in an anaerobic glove box with the headspace filled with pure nitrogen gas. The colonies obtained on the solid mineral medium were further checked for their ability to degrade diuron under anaerobic conditions.

The diuron-degrading isolates were identified based on 16S rDNA gene sequences. The 27F ( $5^{\prime}$ AGAGTTTGATCCTGGCTCAG-3') and 1492R (5'-GGTTACCTTGTTACGACTT-3') primers were used to amplify the $16 \mathrm{~s}$ rRNA in the polymerase chain reaction (PCR). The PCR conditions and bacteria identification have been previously described by $\mathrm{Ha}$ (2018). Initial denaturation step of 2 min duration at $95^{\circ} \mathrm{C}$ was followed by 35 cycles of $95^{\circ} \mathrm{C}, 55^{\circ} \mathrm{C}$, and $72{ }^{\circ} \mathrm{C}, 1 \mathrm{~min}$ each. The final extension was performed for $10 \mathrm{~min}$ at $72{ }^{\circ} \mathrm{C}$. The PCR products were purified using a multiscreen filter plate (Millipore Corp., Bedford, MA, USA). PCR products were sequenced in an automatic sequencer (ABI Prism 3100 Genetic Analyzer, Applied Biosystems, Foster City, CA). Obtained sequences were compared with 16S rRNA gene sequences available in the NCBI database and Ribosomal Database Project.

\section{Diuron degradation in liquid mineral medium (MM)}

The mineral medium (MM) used for diuron degradation studies has been described by Ha and Nguyen (2019). The medium was prepared by adding the following salts to double-distilled water ( $\mathrm{mg} / \mathrm{L}$ ): $\mathrm{Na}_{2} \mathrm{HPO}_{4}-1,419.6, \mathrm{KH}_{2} \mathrm{PO}_{4}-1,360.9, \mathrm{MgCl}_{2}-98.5, \mathrm{CaCl}_{2} \cdot 2 \mathrm{H}_{2} \mathrm{O}-5.88, \mathrm{NaHCO}_{3}-8.4, \mathrm{H}_{3} \mathrm{BO}_{4}-1.16, \mathrm{ZnSO}_{4} \cdot 7 \mathrm{H}_{2} \mathrm{O}-$ 
1.15, $\mathrm{CuSO}_{4} \cdot 5 \mathrm{H}_{2} \mathrm{O}-0.38, \mathrm{CoCl}_{2} \cdot 6 \mathrm{H}_{2} \mathrm{O}-0.24$, and $\mathrm{NaNO}_{3}(1.0 \mathrm{~g} / \mathrm{L})$ acted as the sole nitrogen source and an electron acceptor. The medium was supplemented with glucose $(1.0 \mathrm{~g} / \mathrm{L})$ as a carbon source. After adjusting to $\mathrm{pH} 7.0 \pm 0.1$, the medium was sterilized at $121^{\circ} \mathrm{C}$ for $15 \mathrm{~min}$. Diuron (purity $\geq 98 \%$ ) and other chemicals were purchased from Sigma Aldrich, USA. Diuron was dissolved in absolute ethanol as a stock solution at $0.1 \mathrm{M}$.

Isolated soil bacteria were stored at $-80^{\circ} \mathrm{C}$ as glycerol stocks. Before conducting experiments, each bacterial strain was revived by inoculating in Lysogeny broth (LB) medium for 5 days. Approximately $3 \times 10^{6}$ colony-forming units (CFU) of bacteria were transferred to the MM for the diuron degradation studies. The same number of CFU of each isolate was used for mixed cultures.

\section{Analytical methods}

The chemical concentrations and degradation metabolites were determined through high-performance liquid chromatography (HPLC) and liquid chromatography-mass spectrometer (LC-MS). The sediments, soil and MM were extracted twice with acetone/ethyl acetate $(1 / 1, \mathrm{v} / \mathrm{v})$; samples $(3 \mathrm{~mL})$ were mixed with the extraction solution $(7 \mathrm{~mL})$ and vigorously vortexed for $5 \mathrm{~min}$. The extract was filtered using $0.22 \mu \mathrm{m}$ filters, decanted and evaporated to dryness under nitrogen gas. The residues were dissolved in acetonitrile. The obtained solution was used to determine the remaining substrates and degradation metabolites. The mean recovery efficiencies of diuron from the soil, sediment and liquid MM medium were $93.4 \%, 95.5 \%$ and $96.1 \%$, respectively.

The HPLC system (Shimadzu Corporation, Kyoto, Japan) comprised of LC 20AD pumps, SIL-20A autosampler, and an SPD-M20A photodiode array (PDA) detector. Shimadzu Shim-Pack XR-ODS column was used for the separation of diuron metabolites. The mobile phase consisted of acetonitrile and water $(30: 70, v / v)$ at a flow rate of $0.5 \mathrm{~mL} / \mathrm{L}$ and $5 \mu \mathrm{l}$ sample was injected into the HPLC system. The column oven temperature was maintained at $40^{\circ} \mathrm{C}$. The detection was performed at the wavelength of $250 \mathrm{~nm}$.

The LC-MS analysis was performed using a system of ThermoQuest LCQ Duo (USA). The analyses were separated on a beta basic-C18 HPLC column $(100 \subseteq 2.1 \mathrm{~mm}, 3 \mu \mathrm{m})$. Methanol and water $(6 / 4, \mathrm{v} / \mathrm{v})$ were utilized as the isocratic eluent at a flow rate of $0.2 \mathrm{~mL} / \mathrm{min}$. The sample components were ionized using the electrospray ionization interface with the capillary temperature was set to $27^{\circ} \mathrm{C}$. The mass spectrometer was operated in the MS mode with a $\mathrm{m} / \mathrm{z}$ range of 40 to 450 . Retention time (RT) in HPLC profile and fragmentation in LC-MS were compared to those of authentic standards.

Nitrate, nitrite, and chloride ions present in the culture media were measured according to APHA Method (APHA 2005). The cell growth in the liquid media was evaluated using a spectrophotometer DU800 (Beckman Coulter, Inc, State, USA) at $600 \mathrm{~nm}\left(\mathrm{OD}_{600}\right)$.

\section{Statistical analysis}

All data obtained from at least three experimental replicates are shown as mean \pm standard deviation. Significant differences among means were statistically analyzed using one-way Duncan's test $(p<0.05)$ 


\section{Results}

\section{Diuron degradation by indigenous microorganisms in the sediments and the soil slurries under anaerobic condition}

The diuron degradation capabilities of indigenous microorganisms in the sediments and the soil were significantly different. The time-course of degradation of diuron in the sediments and soil slurries is shown in Fig. 1. In the soil slurry without nutrient amendments, a lag phase was observed for the degradation of diuron by the native microorganisms. However, no lag phase was observed in the soil slurry containing nitrate and glucose. Moreover, the addition of nitrate and glucose increased the degradation performance of both slurries, while diuron dissipation in the sterile samples did not exceed $10 \%$ (Fig. 1). The rate of degradation of diuron in the sediment slurries was significantly higher than that in the soil slurries with or without nutrient amendments. It was observed that $90.0 \pm 3.5 \%$ and $100 \%$ of diuron were dissipated in the soil and sediment slurries supplemented with nitrate and glucose, respectively, after 30 days.

\section{Effect of diuron on the composition of bacterial communities in the soil and sediment slurries}

A total of 21 bacterial genera in the sediment and 22 in the soil, with relative abundance $>1 \%$, were identified. Initially, some genera found in the soil and sediments had similar abundance, including Clostridium and Acinetobacter, but others were significantly different. Alpha diversity (a measure of microbiome diversity in a single sample) was measured using the Chao1, ACE, Shannon, and Simpson indices in the non-sterile slurries of the sediment and the soil. The Operational Taxonomic Units (OTUs) were classified at $97 \%$ similarity. The addition of diuron significantly decreased values of OTUs, ACE, Chao1, and Shannon in both the sediment and the soil at day 15 and day 30. However, the Simpson index for the sediments containing diuron increased at day 15 and day 30 (Table 2). The coverage values of all samples were in the range of 0.982 to 0.994 . The rarefaction curves showed an adequate sequence depth (data not shown). The values of the OTU richness, the Chao1 and Shannon indexes of the soil slurry were lower than those of sediments at both time points. 
Table 2

Diversity and richness of bacterial community in sediments and soil slurries with and without supplementation with diuron

\begin{tabular}{|c|c|c|c|c|c|c|}
\hline & & \multirow{2}{*}{$\begin{array}{l}\text { At the } \\
\text { beginning }\end{array}$} & \multicolumn{2}{|l|}{ Control } & \multicolumn{2}{|l|}{ Diuron } \\
\hline & & & $15 d$ & $30 d$ & $15 d$ & $30 \mathrm{~d}$ \\
\hline \multirow[t]{6}{*}{ Sediment } & Sequences & $\begin{array}{l}41842.0 \pm \\
2593.3^{c}\end{array}$ & $\begin{array}{l}38513.7 \pm \\
3695.4^{\mathrm{bc}}\end{array}$ & $\begin{array}{l}35689.7 \pm \\
3072.1^{\mathrm{ab}}\end{array}$ & $\begin{array}{l}31481.0 \pm \\
3411.9^{a}\end{array}$ & $\begin{array}{l}32206.3 \pm \\
3281.9^{a}\end{array}$ \\
\hline & OTUs & $\begin{array}{l}1442.8 \pm \\
89.4^{d}\end{array}$ & $\begin{array}{l}1167.1 \pm \\
112.0^{c}\end{array}$ & $\begin{array}{l}1115.3 \pm \\
96.0^{b c}\end{array}$ & $\begin{array}{l}874.5 \pm \\
94.8^{\mathrm{ab}}\end{array}$ & $\begin{array}{l}970.1 \pm \\
98.9^{a}\end{array}$ \\
\hline & ACE & $\begin{array}{l}1781.3^{ \pm} \\
110.4^{\mathrm{c}}\end{array}$ & $\begin{array}{l}1515.7 \pm \\
145.4^{\mathrm{b}}\end{array}$ & $\begin{array}{l}1487.1 \pm \\
128.0^{\mathrm{a}}\end{array}$ & $\begin{array}{l}1197.9 \pm \\
129.8^{a}\end{array}$ & $\begin{array}{l}1293.4 \pm \\
131.8^{\mathrm{ab}}\end{array}$ \\
\hline & Chao1 & $\begin{array}{l}2020.0^{ \pm} \pm \\
125.2^{c}\end{array}$ & $\begin{array}{l}1809.0 \pm \\
173.6^{\mathrm{b}}\end{array}$ & $\begin{array}{l}1784.5 \pm \\
153.6^{\mathrm{bc}}\end{array}$ & $\begin{array}{l}1416.6 \pm \\
153.5^{a}\end{array}$ & $\begin{array}{l}1590.9 \pm \\
162.1^{\mathrm{ab}}\end{array}$ \\
\hline & Simpson & $\begin{array}{l}0.062 \pm \\
0.004^{\mathrm{a}}\end{array}$ & $\begin{array}{l}0.070 \pm \\
0.006^{\mathrm{ab}}\end{array}$ & $\begin{array}{l}0.086 \pm \\
0.010^{\mathrm{bc}}\end{array}$ & $\begin{array}{l}0.097 \pm \\
0.008^{\text {cd }}\end{array}$ & $\begin{array}{l}0.109 \pm \\
0.013^{d}\end{array}$ \\
\hline & Shannon & $6.2 \pm 0.5^{b}$ & $5.8 \pm 0.5^{b}$ & $5.7 \pm 0.5^{b}$ & $4.7 \pm 0.4^{\mathrm{a}}$ & $4.2 \pm 0.4^{\mathrm{a}}$ \\
\hline \multirow[t]{6}{*}{ Soil } & Sequences & $\begin{array}{l}33607.7 \pm \\
1575.7^{c}\end{array}$ & $\begin{array}{l}28346.0 \pm \\
2475.5^{b}\end{array}$ & $\begin{array}{l}27822.0 \pm \\
2638.1^{b}\end{array}$ & $\begin{array}{l}22980.0 \pm \\
2509.2^{\mathrm{a}}\end{array}$ & $\begin{array}{l}22705.3 \pm \\
2731.3^{a}\end{array}$ \\
\hline & OTUs & $\begin{array}{l}1080.6 \pm \\
50.7^{c}\end{array}$ & $\begin{array}{l}944.9 \pm \\
82.5^{b c}\end{array}$ & $\begin{array}{l}869.4 \pm \\
82.4^{b}\end{array}$ & $\begin{array}{l}647.3 \pm \\
70.7^{a}\end{array}$ & $\begin{array}{l}679.8 \pm \\
81.8^{a}\end{array}$ \\
\hline & ACE & $\begin{array}{l}1350.8 \pm \\
63.3^{d}\end{array}$ & $\begin{array}{l}1259.8 \pm \\
110.0^{\text {cd }}\end{array}$ & $\begin{array}{l}1100.6 \pm \\
104.4^{\mathrm{bc}}\end{array}$ & $\begin{array}{l}809.2 \pm \\
88.4^{a}\end{array}$ & $\begin{array}{l}944.2 \pm \\
113.6^{\mathrm{ab}}\end{array}$ \\
\hline & Chao1 & $\begin{array}{l}1404.8 \pm \\
65.9^{c}\end{array}$ & $\begin{array}{l}1237.8^{\circ} \\
108.1^{\mathrm{c}}\end{array}$ & $\begin{array}{l}1173.7 \pm \\
111.3^{\mathrm{bc}}\end{array}$ & $\begin{array}{l}932.1 \pm \\
101.8^{a}\end{array}$ & $\begin{array}{l}951.7 \pm \\
114.5^{a}\end{array}$ \\
\hline & Simpson & $\begin{array}{l}0.101 \pm \\
0.005^{\mathrm{a}}\end{array}$ & $\begin{array}{l}0.118 \pm \\
0.011^{\mathrm{ab}}\end{array}$ & $\begin{array}{l}0.132 \pm \\
0.016^{\mathrm{b}}\end{array}$ & $\begin{array}{l}0.141 \pm \\
0.013^{b}\end{array}$ & $\begin{array}{l}0.140 \pm \\
0.015^{b}\end{array}$ \\
\hline & Shannon & $4.8 \pm 0.5^{c}$ & $4.5 \pm 0.5^{c}$ & $4.2 \pm 0.4^{b c}$ & $3.6 \pm 0.4^{\mathrm{ab}}$ & $3.8 \pm 0.4^{a}$ \\
\hline
\end{tabular}

During incubation, both genera and phyla changed with more significant shifts occurring in the media containing diuron (Fig. 2 \& Fig. 3). Some genera disappeared in both the sediment and the soil slurries, while others became dominant in the media containing diuron. In the sediments, three genera showed abundance $>10 \%$, i.e., Pseudomonas (10.5\%), Dechloromonas (14.0\%) and Thiobacillus (17.5\%) after one month. Whereas three genera were dominant in the soil, i.e., Pseudomonas (15.5\%), Azoarcus (14.4\%), 
and Thauera (12.7\%). No genus abundance exceeded $10 \%$ in the slurries without diuron at the end of the incubation period.

Initially, Proteobacteria, Firmicutes, Euryarchaeota, and Actinobacteria were the main bacterial phyla in both the sediments and soil slurries, whereas Bacteroidetes was relatively abundant in the soil samples only (Fig. 3). After one month of incubation, the abundance of Proteobacteria and Euryarchaeota increased in both slurries. The abundance of Firmicutes decreased in both the soil and the sediment after one month of incubation; however, they were still the second most abundant phyla in the sediment and the third most abundant phyla in the soil. At the end of 30 days of incubation, the most significant increase in abundance of Proteobacteria was observed in the presence of diuron. The relative abundance of Proteobacteria increased from $38.8 \%$ at $\mathrm{T}_{0}$ to $63.1 \%$ at the end of 30 day incubation in the sediment and from $52.2-72.7 \%$ in the soil slurry containing diuron. These findings indicate a major role of the phylum in the anaerobic degradation of diuron in the soil and the sediments.

\section{Isolation and identification of diuron-degrading bacteria from sediment and soil slurries}

After 30 days of enrichment, several bacterial strains, which degraded diuron under anaerobic conditions using nitrate as an electron acceptor, were isolated and identified. Three strains were isolated from sediments: (Thauera aromatica DT1 (MT974432), Azoarcus sp. DT2 (MT974431), and Pseudomonas sp. MT (MT974595)) and three strains were isolated from the soil: Dechloromonas aromatica DU (MT975261), Thiobacillus denitrificans DR (MT974433) and Pseudomonas sp. MS (MT974435).

\section{Diuron degradation by pure and mixed cultures}

The diuron degradation rate and the cell growth were greater for the mixed culture isolated from the sediments than that for the mixed culture isolated from the soil. The time-course of degradation of diuron by mixed cultures isolated from the sediments and the soil is presented in Fig. 4 . The addition of glucose increased the degradation and the growth rates. Both mixed cultures could utilize diuron as a carbon source, but the addition of glucose increased the degradation and the growth rates.

Diuron degradation rates of the single isolates were significantly lower than that of the mixed cultures. Diuron degraded by the bacterial strains isolated from the sediment, T. aromatica DT1, Azoarcus sp. DT2, Pseudomonas sp. MT was $78.4 \pm 6.7 \%, 72.8 \pm 6.4 \%$, and $60.2 \pm 7.2 \%$, respectively, after 30 days of incubation. In comparison, mixed culture of bacteria isolated from the sediment degraded $95.5 \pm 3.0 \%$ of diuron in this duration. The corresponding values for the bacterial strains isolated from the soil, $D$. aromatica DU, T. denitrificans DR, Pseudomonas sp. MS and the mixture of these were $55.4 \pm 6.5 \%, 62.5$ $\pm 5.3 \%, 68.8 \pm 7.1 \%$ and $84.5 \pm 4.5 \%$ (Fig. 5).

Moreover, the degradation performances of mixed cultures of two isolates were slower than those of three isolates (data not shown). The mixture of all bacterial strains isolated from the soil and sediments degraded $90.5 \% \pm 4.4 \%$ of diuron after 30 days, which was not statistically different from mixed cultures of three strains from the sediment and soil. 


\section{Transformation of electron acceptor and production of $\mathrm{Cl}^{-}$ during diuron degradation}

In mineral medium, the anaerobic degradation was observed only in the presence of nitrate. Nitrate was not transformed in the medium without bacteria. During the growth of the two consortia in the mineral medium, nitrate was consumed, and nitrite and chloride were released (Table 3). The ratios of the nitrite produced to the nitrate consumed in the mixed culture isolated from sediments and soil slurries were $80.4 \% \pm 14.4 \%$ and $65.4 \% \pm 5.4 \%$, respectively. The corresponding ratios of the produced chloride to theoretically produced chloride were $92.1 \% \pm 5.7 \%$ and $88.4 \% \pm 5.7 \%$, respectively. The degradation by all isolates was negligible under aerobic conditions.

Table 3

Nitrate consumed, nitrite produced, and chloride released during diuron degradation by mixed cultures Concentration $(\mu \mathrm{M})$

$\begin{array}{ll}\text { Mixed pure culture isolated } & \begin{array}{l}\text { Mixed pure culture isolated from } \\ \text { from sodiment }\end{array}\end{array}$

Diuron degradation

$72.5 \pm 4.7$

$82.8 \pm 2.1$

$1177.6 \pm 77.6$

$1144.9 \pm 82.8$

$\mathrm{NO}_{3}$ consumed

$936.4 \pm 101.1$

$748.1 \pm 42.9$

$\mathrm{NO}_{2}$ produced

$\mathrm{Cl}^{-1}$ released

$103.7 \pm 8.7$

$105.8 \pm 10.7$

$\mathrm{Cl}^{-1}$ produced $/ \mathrm{Cl}^{-1}$ produced

$92.1 \pm 5.7$

$88.4 \pm 5.7$

theoretically*

Metabolites produced

$\begin{array}{lll}\text { DCPU } & 7.4 \pm 0.8 & 8.2 \pm 1.1 \\ \text { CPDMU } & 6.5 \pm 0.7 & 7.1 \pm 0.7 \\ \text { 3,4-DCA } & 3.8 \pm 0.5 & 4.2 \pm 0.5 \\ \text { 4-chloroaniline } & - & 3.5 \pm 0.4 \\ \text { Aniline } & 2.1 \pm 0.4 & -\end{array}$

* The amount of $\mathrm{Cl}^{-1}$ theoretically produced was calculated based on the concentrations of substrates transformed and chloride remaining in the intermediates. 


\section{Identification of metabolites produced by diuron degradation}

During the anaerobic degradation of diuron, several intermediate products were detected (Table 4). DCPU, CPDMU, and 3,4-DCA were the main metabolites with relatively high levels of concentration (Table 3) and found in all treatments (Table 4). Chlorobenzene was only detected in sediment slurries. 4-chloroaniline was not detected in mixed pure cultures isolated from the sediment, while aniline was not found in the mixed pure culture isolated from the soil (Table 4).

Table 4. Diuron metabolites produced by the indigenous anaerobic microorganism in the sediment and soil slurries and the isolated consortia from the sediment and soil. The MM supplemented with nitrate and glucose was used for growth of the isolated microorganisms

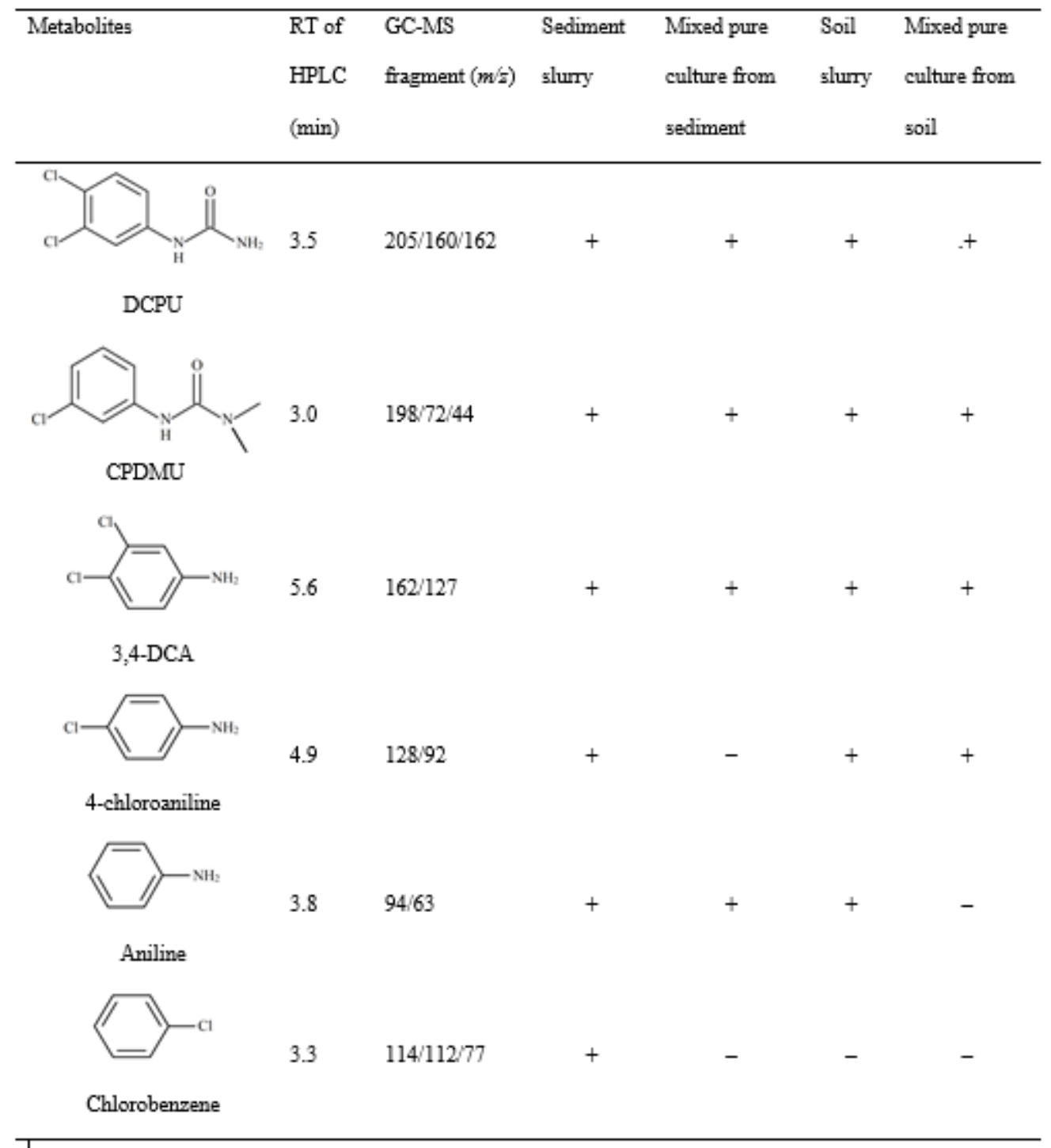

\section{Discussion}

Diuron degradation by indigenous microorganisms in the sediments did not require a lag phage and was higher than that by indigenous microorganisms in the soil. Moreover, the degradation capability of the 
mixed bacterial culture isolated from the sediments was higher than that of the mixed bacterial culture isolated from the soil. The degradation of diuron in soil under natural conditions depends on the soil type and the microbial composition. The microbial community of the sediments could have a long history of chronic exposure to the pollutant, resulting in adaptation to its degradation. In one study, diuron degradation in the soil was found to be slow, with only $5 \%-25 \%$ of the herbicide dissipated after 29 days under aerobic conditions after first application; however, subsequent applications of diuron to the soil caused rapid degradation of the herbicide (Cullington and Walker 1999).

The diuron degradation occurred in the soil and the sediment without added nitrate, indicating that the naturally occurring nitrate and possibly other components in these media served as electron acceptors. Anoxic environment and nitrate-reducing conditions typically exist in sediments and flooded lands, which may stimulate anaerobic biotransformation of herbicides in these environments. The addition of nitrate and glucose significantly increased the degradation rates. Nitrate served as an electron acceptor and nitrogen source, whereas glucose was a carbon source. Improvement in the degradation rates of sediment slurries under anaerobic conditions owing to the addition of cosubstrates have been reported (Attaway et al. 1982a, b). Attaway et al. (1982a) showed that diuron (at $40 \mathrm{mg} \mathrm{L}^{-}$) was completely degraded in the sediments after 25 days under anaerobic conditions.

During anaerobic degradation of diuron, denitrification was observed. The amounts of nitrate consumed were significantly higher than that of nitrite produced, probably because nitrate was transformed into nitrogen gas, and/or nitrate served as a nitrogen source for the bacteria. The amounts of chloride produced were lower than the theoretical amounts. This result could be attributed to the chloride absorption by bacteria, retention of chloride in unknown metabolites, or both. These phenomena were also for anaerobic degradation of other organic compounds (Ha 2018; Ha and Nguyen 2019).

The abundance of various bacterial strains in the microbial community varied with time during the incubation in both the sediment and the soil samples. More extensive shifts in the bacterial community were observed in media containing diuron. The high coverage value in soil and sediment samples revealed that the sequencing depth was enough to capture the diversity of the bacterial community in this study. The decrease in Shannon and increase in Simpson indexes compared to initial soil and sediment samples showed a reduction in the biodiversity of the microbial community during the incubation. The biodiversity in the slurries declined during incubation, which indicated that some bacteria were killed due to toxic effects of diuron. However, some species and phyla became dominant after 30 days of incubation, indicating a positive selection for the bacterial strains capable of metabolizing diuron. El Fantroussi et al. (2000) reported that bacterial diversity decreased for an extended period under aerobic conditions after phenylurea herbicides diuron and linuron were applied. Some species were eliminated from the community after treatment with these herbicides (El Fantroussi et al. 2000). In another study, atrazine and diuron affected the bacterial community in the soil more significantly than 2,4dichlorophenoxyacetic acid (Moretto et al. 2017). Moretto et al. (2017) showed that the richness of a microbial community reduced after four weeks and recovered at the eighth week after diuron application. 
The persistence of diuron in the soil significantly influenced the distribution of the bacterial community (Moretto et al. 2017).

Two bacterial consortia isolated in this study, one from the soil and the other from sediment slurries, showed effective diuron degrading activities. The degradation by each consortium was higher than all individual strains. These results indicate a synergistic activity in the degradation of the parent compound and its metabolites by the microbial community in slurries. Previous studies have also indicated that the anaerobic degradation of complex organic compounds is mainly carried out by mixed cultures (Ghattas et al. 2017; Duc 2019). The cooperation between microbial populations to degrade diuron and other metabolites in soil under aerobic conditions has also been described (Villaverde et al. 2017). Native bacteria in sediment and soil bacteria had adapted to specific conditions and exhibited synergistic interactions for herbicide degradation. The compatible bacterial strains can enhance the degradation of organic compounds (Duc 2019; Oanh and Duc 2021).

Several diuron metabolites DCPMU, DCPU, and 3,4-DCA, produced during degradation under anoxic conditions, have been identified (Stasinakis et al. 2009). However, all metabolites were not further metabolized under the anoxic conditions, even though they were transformed under the aerobic condition (Stasinakis et al. 2009). In this study, DCPU, 3,4-DCA, CPDMU, and some other products were formed during degradation by indigenous microorganisms and isolated bacteria. CPDMU has been found to be produced during anaerobic degradation of diuron, but a further transformation of this compound is unclear (Attaway et al. 1982a, 1982b; Stepp et al. 1985). DCPU is a major metabolite produced under anoxic conditions, and 3,4-DCA is only produced when an external carbon is supplemented (Shareef et al. 2014). 3,4-DCA is accumulated as a final diuron degradation product (Tixier et al. 2000; Giacomazzi and Cochet 2004) and is more persistent than its parent compound (Tixier et al. 2000). In this study, 3,4-DCA was further metabolised to produce 4-chloroaniline, aniline, and chlorobenzene, and similar findings have been reported by others (Ha and Nguyen 2019). DCMPU is usually produced during diuron degradation under aerobic conditions and is sometimes formed under anoxic conditions (Stasinakis et al. 2009). However, DCMPU was not detected in this study.

\section{Conclusion}

Diuron could be degraded by indigenous microorganisms in soil and sediment slurries under anaerobic conditions, and the supplementation of nitrate and glucose increased the diuron degradation. However, the microbial diversity structures in these media decreased with the addition of diuron. Thauera aromatica DT1, Azoarcus sp. DT2, and Pseudomonas sp. MT isolated from sediments, and Dechloromonas aromatica DU, Thiobacillus denitrificans DR, and Pseudomonas sp. MS isolated from soil slurry isolated in this study were the first pure cultures that could degrade diuron under anaerobic conditions, to the best of our knowledge. These results may contribute to understanding the microbial community response to diuron and the metabolites of diuron degradation under anaerobic conditions.

\section{Declarations}




\section{Acknowledgments}

This work was supported by Dong Thap University. We are very thankful for all supports and encouragements during our conducting this research.

\section{References}

APHA (2005) Standard Methods for the Examination of Water and Waste Water. 21st ed. Washington, DC: American Public Health

Attaway HH, Camper ND, Paynter MJB (1982a) Anaerobic microbial degradation of diuron by pond sediment. Pestic Biochem Physiol 17(1):96-101. https://doi.org/10.1016/0048-3575(82)90130-4

Attaway HH, Paynter MJB, Camper ND (1982b) Degradation of selected phenylurea herbicides by anaerobic pond sediment. J Environ Sci Health B 17:683-699

Bolger AM, Lohse M, Usadel B (2014) Trimmomatic: a flexible trimmer for Illumina sequence data. Bioinf 30(15):2114-2120. https://doi.org/10.1093/bioinformatics/btu170

Coelho-Moreira JS, Bracht A, Souza ACS, Oliveira RF, Sa-Nakanishi AB, Souza CGM, Peralta RM (2013) Degradation of diuron by Phanerochaete chrysosporium: role of ligninolytic enzymes and cytochrome P450. Biomed Res Int 2013:251354. https://doi.org/10.1155/2013/251354

Coelho-Moreira JS, Brugnari T, Sá-Nakanishi AB, Castoldi R, de Souza CGM, Bracht A, Peralta RM (2018) Evaluation of diuron tolerance and biotransformation by the white-rot fungus Ganoderma lucidum. Fungal Biol 122(6):471-478. https://doi.org/10.1016/j.funbio.2017.10.008

Cullington JE, Walker A (1999) Rapid biodegradation of diuron and other phenylurea herbicides by a soil bacterium. Soil Biol Biochem 31:677-686. https://doi.org/10.1016/s0038-0717(98)00156-4

Devers-Lamrani M, Pesce S, Rouard N, Martin-Laurent F (2014) Evidence for cooperative mineralization of diuron by Arthrobactersp. BS2 and Achromobactersp. SP1 isolated from a mixed culture enriched from diuron exposed environments. Chemosphere 117:208-

215. https://doi.org/10.1016/j.chemosphere.2014.06.080

Dores E, Spadotto C, Weber O, Carbo L, Vechiato A, Pinto A (2009) Environmental behaviour of metolachlor and diuron in a tropical soil in the central region of Brazil. Water Air Soil Pollut 197:175183. https://doi.org/10.1007/s11270-008-9801-1

Duc HD (2019) Anaerobic degradation of 2-chloro-4-nitroaniline by Geobacter sp. KT7 and Thauera aromaticaa KT9. FEMS Microbiol Lett 366(14):fnz174. https://doi.org/10.1093/femsle/fnz174

Egea TC, da Silva R, Boscolo M, Rigonato J, Monteiro DA, Grünig D, da Silva H, van der Wielen F, Helmus R, Parsons JR, Gomes E (2017) Diuron degradation by bacteria from soil of sugarcane crops. Heliyon 
3(12):e00471. https://doi.org/10.1016/j.heliyon.2017.e00471

El-Fantroussi S, Verstraete W, Top EM (2000) Enrichment and molecular characterization of a bacterial culture that degrades methoxymethyl urea herbicides and their aniline derivatives. Appl Environ Microbiol 66(12):5110-5115. https://doi.org/10.1128/aem.66.12.5110-5115.2000

Ellegaard-Jensen L, Aamand J, Kragelund BB, Johnsen AH, Rosendahl S (2013) Strains of the soil fungus Mortierella show different degradation potentials for the phenylurea herbicide diuron. Biodegradation 24(6):765-774. https://doi.org/10.1007/s10532-013-9624-7

Felício AA, Freitas JS, Scarin JB, de Souza Ondei L, Teresa FB, Schlenk D, de Almeida EA (2018) Isolated and mixed effects of diuron and its metabolites on biotransformation enzymes and oxidative stress response of Nile tilapia (Oreochromis niloticus). Ecotoxicol Environ Saf 149:248256. https://doi.org/10.1016/j.ecoenv.2017.12.009

Field JA, Reed RL, Sawyer TE, Griffith SM, Wigington PJJr (2003) Diuron occurrence and distribution in soil and surface and ground water associated with grass seed production. J Environ Qual 32(1):171179. https://doi.org/10.2134/jeq2003.171

Ghattas A-K, Fischer F, Wick A, Ternes TA (2017) Anaerobic biodegradation of (emerging) organic contaminants in the aquatic environment. Water Res 116(1):268295. https://doi.org/10.1016/j.watres.2017.02.001

Giacomazzi S, Cochet N (2004) Environmental impact of diuron transformation: a review. Chemosphere 56(11):1021-1032. https://doi.org/10.1016/j.chemosphere.2004.04.061

Gooddy DC, Chilton PJ, Harrison I (2002) A field study to assess the degradation and transport of diuron and its metabolites in a calcareous soil. Sci Total Environ 297(1-3):67-

83. https://doi.org/10.1016/s0048-9697(02)00079-7

Ha DD (2018) Anaerobic degradation of 2,4-dichlorophenoxyacetic acid by Thauera sp DKT. Biodegradation 29:499-510. https://doi.org/10.1007/s10532-018-9848-7.

Ha D.D Nguyen TO (2019) Anaerobic degradation of chloroanilines by Geobactersp KT5. Curr Microbiol 76:248-257. https://doi.org/10.1007/s00284-018-1617-7

Hanapiah M, Zulkifli SZ, Mustafa M, Mohamat-Yusuff F, Ismail A (2018) Isolation characterization and identification of potential diuron-degrading bacteria from surface sediments of Port Klang Malaysia. Mar Pollut Bull 127:453-457. https://doi.org/10.1016/j.marpolbul.2017.12.015

Landry D, Sylvie D, Andreux F (2006) Leaching of oryzalin and diuron through undisturbed vineyard soil columns under outdoor conditions. Chemosphere 62:1737-

1747. https://doi.org/10.1016/j.chemosphere.2005.06.024. 
Magoč T, Salzberg SL (2011) FLASH: fast length adjustment of short reads to improve genome assemblies. Bioinformatics, 27:2957-2963. https://doi.org/10.1093/bioinformatics/btr507

Malato S, Blanco J, Caceres J, Fernandez-Alba AR, Aguera A, Rodriguez A (2002) Photocatalytic treatment of water-soluble pesticides by photo-Fenton and $\mathrm{TiO}_{2}$ using solar energy. Catal Today 76:209220. https://doi.org/10.1016/S0920-5861(02)00220-1

Matthai C, Guise K, Coad P, McCready S, Taylor S (2009) Environmental status of sediments in the lower Hawkesbury-Nepean River New South Wales. Aust. J Earth Sci 56:225-

243. https://doi.org/10.1080/08120090802547058

Moretto JAS, Altarugio LM, Andrade PA, Fachin AL, Andreote FD, Stehling EG (2017) Changes in bacterial community after application of three different herbicides. FEMS Microbiol Lett 364(13):fnx113. https://doi.org/10.1093/femsle/fnx113

Muendo BM, Shikuku VO, Lalah JO, Getenga ZM, Wandiga SO, Rothballer M (2021) Enhanced degradation of diuron by two Bacillus species isolated from diuron contaminated sugarcane and pineapple-cultivated soils in Kenya. Appl Soil Ecol

157:103721. https://doi.org/10.1016/j.apsoil.2020.103721

Prado AG, Airoldi C (2001) The effect of the herbicide diuron on soil microbial activity. Pest Manag Sci 57(7):640-644. https://doi.org/10.1002/ps.321

Shareef A, Page D, Vanderzalm J, Williams M, Gupta VVSR, Dillon P, Kookana R (2014) Biodegradation of simazine and diuron herbicides under aerobic and anoxic conditions relevant to managed aquifer recharge of storm water. Clean-Soil Air Water 42:745-752. https://doi.org/10.1002/clen.201300092

Sørensen SR, Bending GD, Jacobsen CS, Walker A, Aamand J (2003) Microbial degradation of isoproturon and related phenylurea herbicides in and below agricultural fields. FEMS Microbiol Ecol 45(1):1-11. https://doi.org/10.1016/S0168-6496(03)00127-2

Stasinakis AS, Kotsifa S, Gatidou G, Mamais D (2009) Diuron biodegradation in activated sludge batch reactors under aerobic and anoxic conditions. Water Res 43(5):14711479. https://doi.org/10.1016/j.watres.2008.12.040

Stepp TD, Camper ND, Paynter MJB (1985) Anaerobic microbial degradation of selected 34dihalogenated aromatica compounds. Pestic Biochem Physiol 23:256260. https://doi.org/10.1111/1751-7915.13488

Thomas KV, Fileman TW, Readman JW, Waldock M (2001) Antifouling paint booster biocides in the UK coastal environment and potential risks of biological effects. Mar Pollut Bull 42(8):677688. https://doi.org/10.1016/s0025-326x(00)00216-2 
Tixier C, Bogaerts P, Sancelme M, Bonnemoy F, Twagilimana L, Cuer A, Bohatier J, Veschambre H (2000) Fungal biodegradation of a phenylurea herbicide diuron: structure and toxicity of metabolites. Pest Manag Sci 56:455-462. https://doi.org/10.1002/(SICI)1526-4998(200005)56:5<455::AIDPS152>3.0.C0;2-Z

Villaverde J, Rubio-Bellido M, Merchán F, Morillo E (2017) Bioremediation of diuron contaminated soils by a novel degrading microbial consortium. J Environ Manage 188:379386. https://doi.org/10.1016/j.jenvman.2016.12.020

Wang Q, Garrity GM, Tiedje JM, Cole JR (2007) Naive Bayesian classifier for rapid assignment of rRNA sequences into the new bacterial taxonomy. Appl Environ Microbiol 73(16):52615267. https://doi.org/10.1128/AEM.00062-07

Wauchope RD, Buttler TMHAG, Augustijn-Beckers PWM, Burt JP (1992) SCS/ARS/CES pesticides properties database for environmental decision making. Rev Environ Contam Toxicol 123:1157. https://doi.org/10.1007/978-1-4612-2862-2_1

\section{Figures}
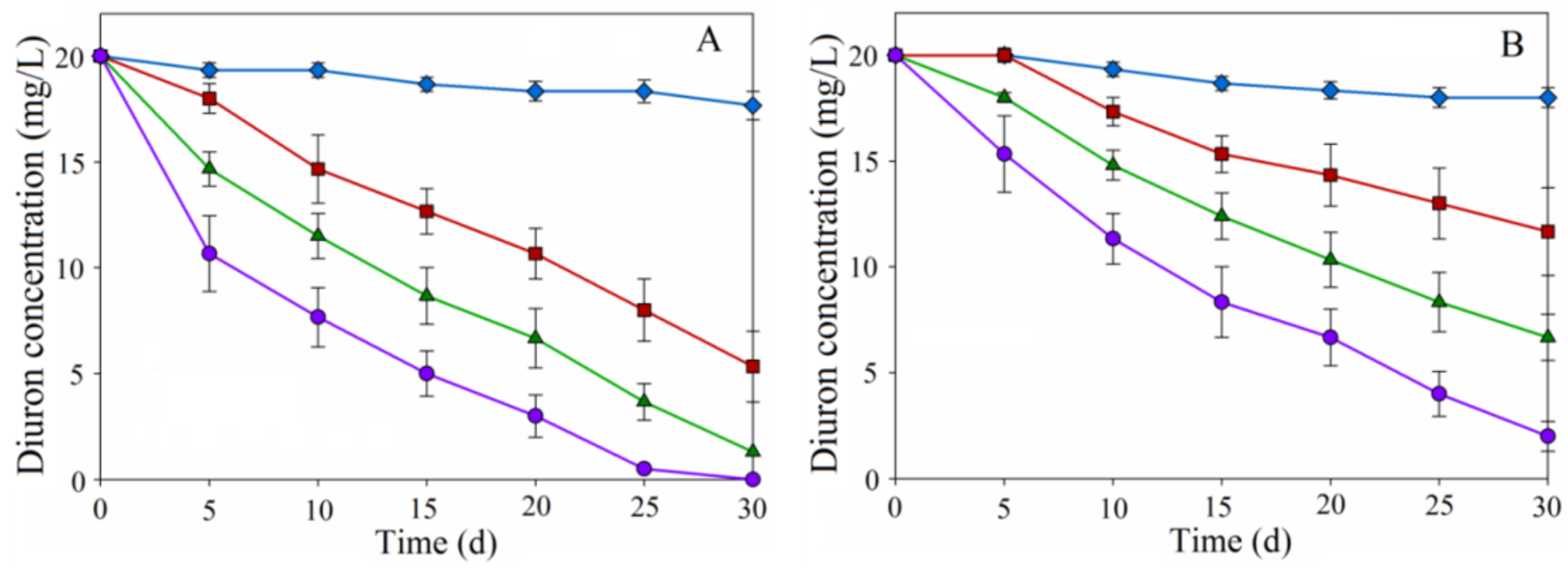

\section{Figure 1}

Diuron degradation by indigenous microorganisms in the sediment $(A)$ and soil (B) slurries in sterile samples (diamond), non-sterile samples (square), non-sterile samples amended with nitrate (triangle), and non-sterile samples amended with nitrate and glucose (circle) 

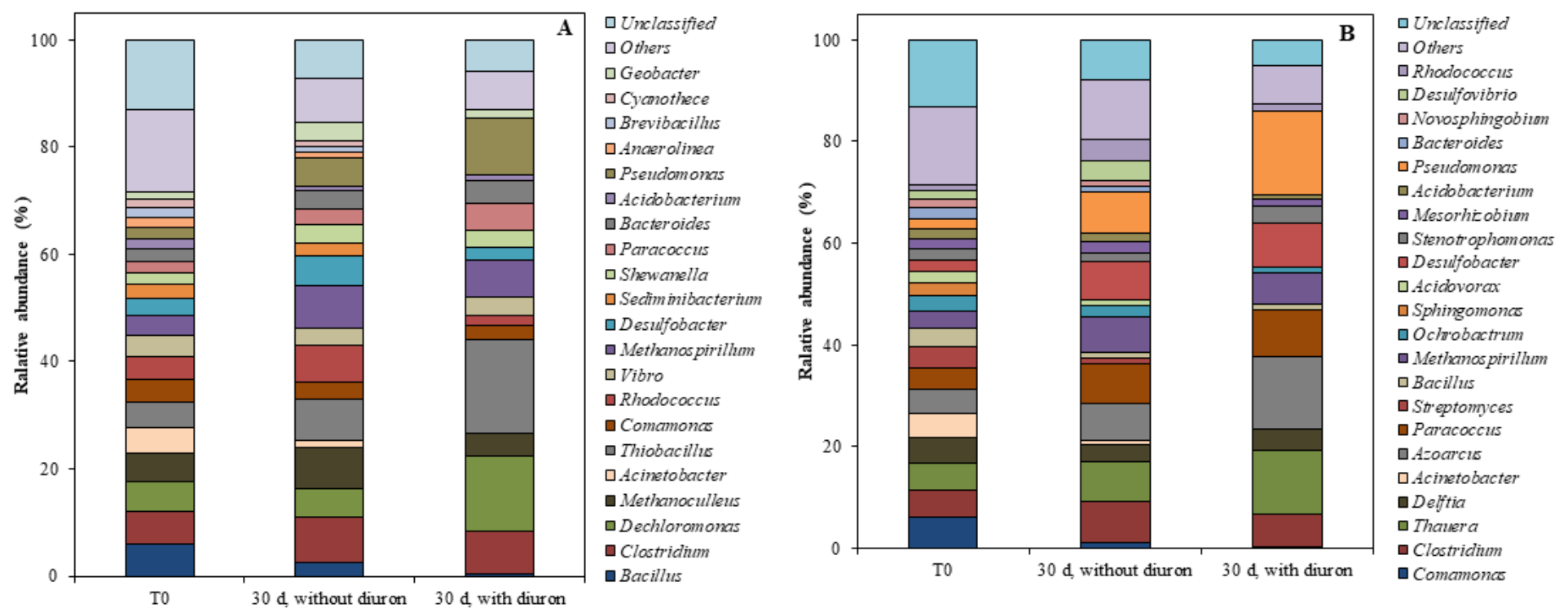

Figure 2

Relative abundance of bacteria at genus levels in (A) soil and (B) sediment slurries at T0 (at the beginning), and after 30 days of incubation with and without diuron. The nitrate was added to the slurries but not glucose. "Other" represents all the classified taxa $<1 \%$. "Unclassified" denotes sequences that could not be classified into any known genus 

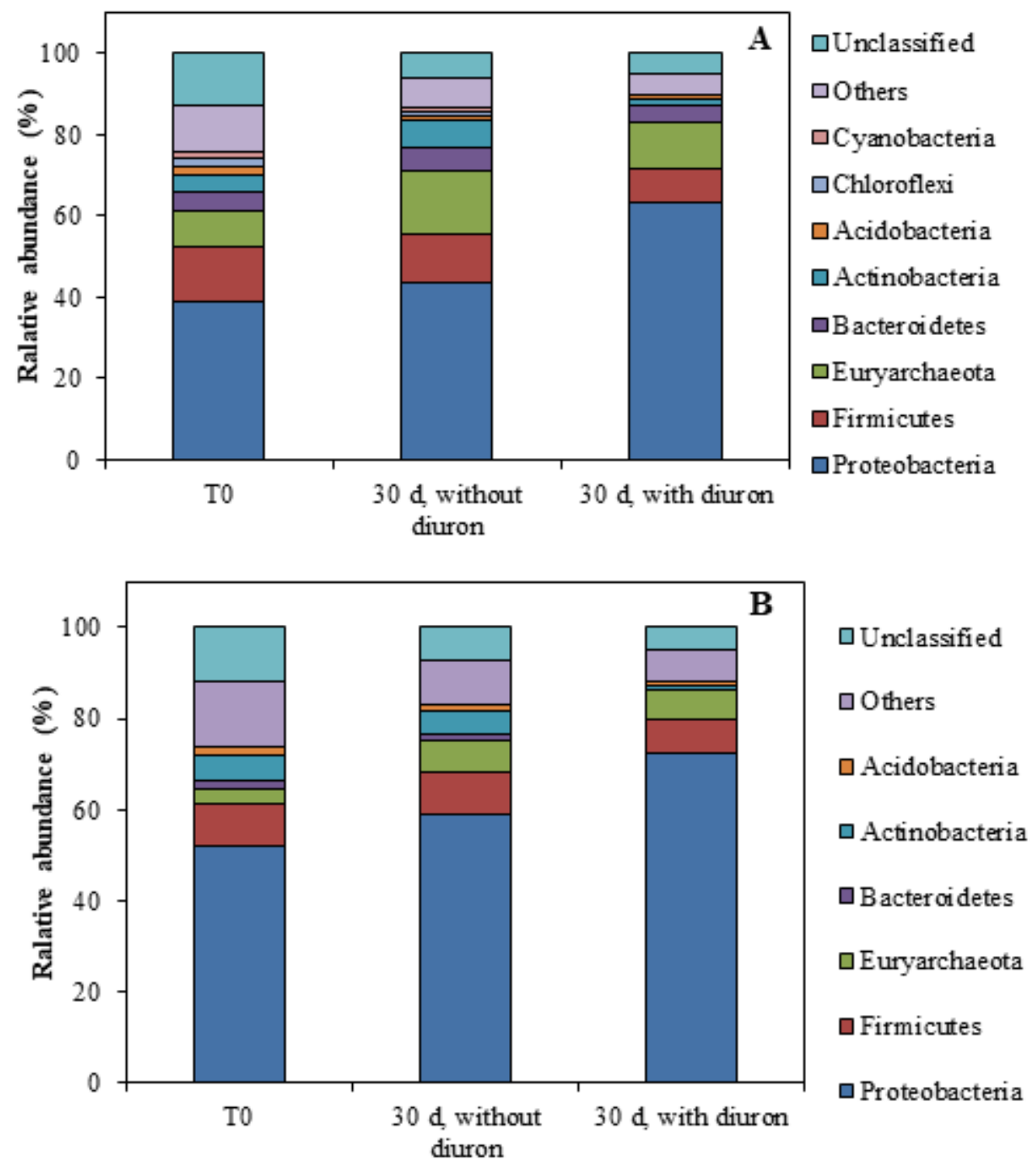

Figure 3

Relative abundance of bacteria at phylum levels in (A) soil and (B) sediment slurries at T0 (at the beginning) and after 30 days of incubation with and without diuron. The nitrate was added to the slurries but not glucose. "Unclassified" denotes sequences that could not be classified into any known genus
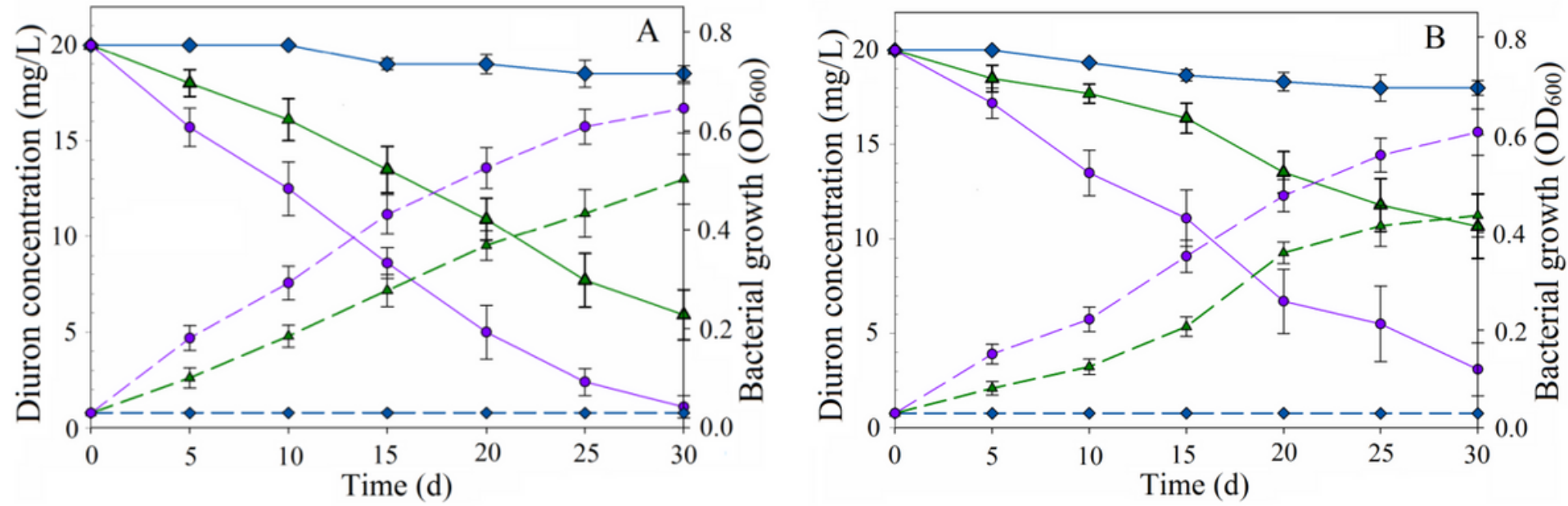
Figure 4

Diuron degradation (solid line) and cell growth (dashed line) by mixed pure cultures isolated from (A) sediment and (B) soil in MM with glucose (circle) and without glucose (triangle). Nitrate was used as an electron acceptor. The abiotic degradation (diamond) was also carried out in parallel

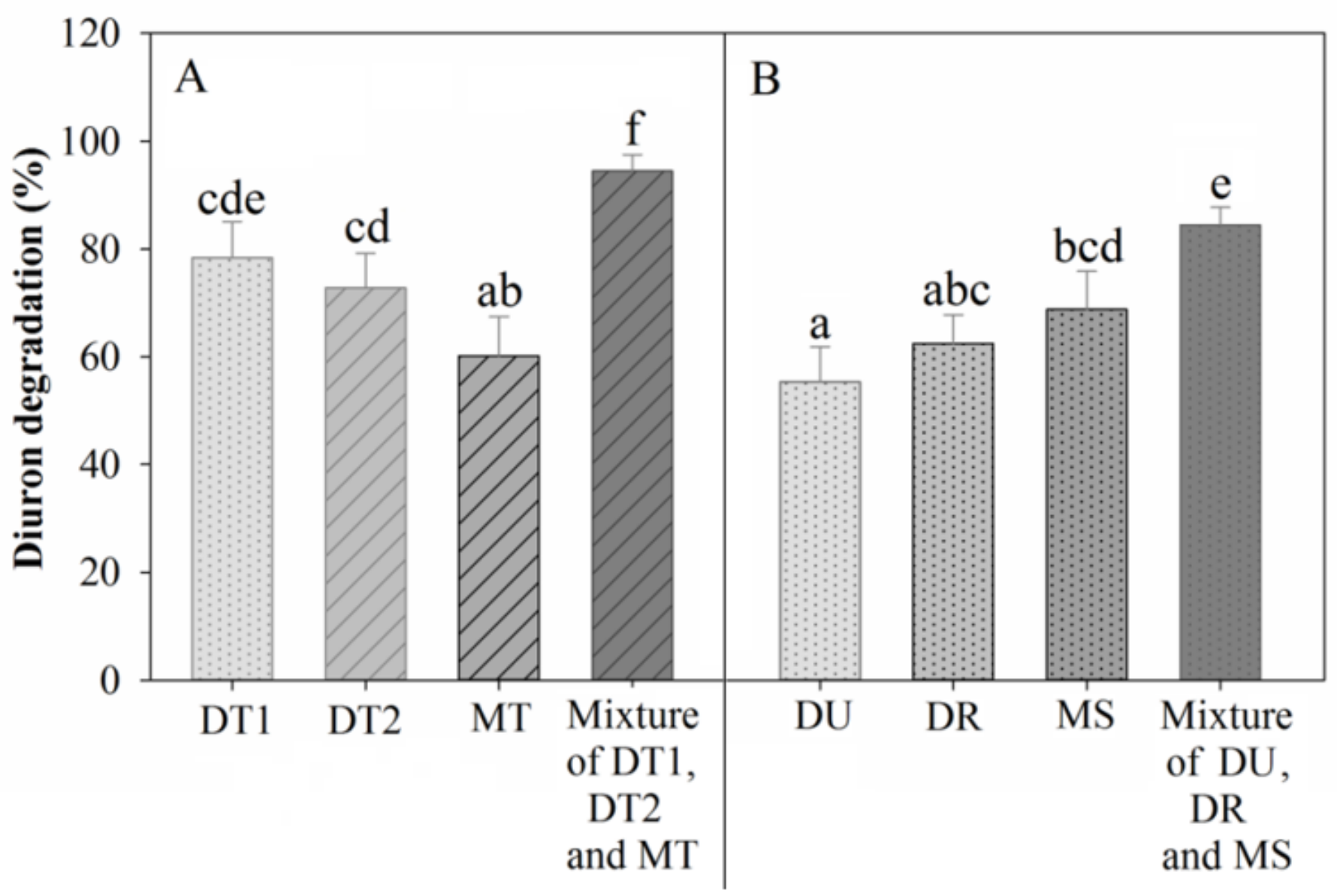

Figure 5

Diuron degradation by the individual strains and the mixed cultures of the bacterial strains isolated from (A) sediment and (B) soil. T. aromatica DT1, Azoarcus sp. DT2, and Pseudomonas sp. MT were isolated from the sediment and D. aromatica DU, T. denitrificans DR and Pseudomonas sp. MS were isolated from the soil. Diuron degradation was carried out in mineral medium supplemented with nitrate and glucose. The error bars indicate the standard deviation, and different letters in lower case (a-f) represent significant differences among treatments $(p<0.05)$ 